\title{
Financial Sector Development and Economic Growth in Ethiopia: Literature Review
}

\author{
Mesele Shiferaw Kotiso \\ Assistant Professor In Accounting And Finance, Wolaita Sodo University, \\ College Of Business And Economics, Ethiopia
}

\begin{abstract}
The financial sector and its role in the process of economic development have attracted notable attention since the early 1990s. Long-term sustainable economic growth depends on the ability to raise the rates of accumulation of physical and human capital, to use the resulting productive assets more efficiently, and to ensure the access of the whole population to these assets right now, Ethiopian financial sector is not serving needs of the economy Most of the economies in the country didn't efficiently mobilize their domestic financial resources These phenomenon's can in part be attributed to lack of a well developed financial sector (such as capital markets, banks, and other financial institutions) and the poor economic policies and incompetent "institutions" in the country. This article presents the general overview of Financial Sector Development and Economic Growth in Ethiopia by reviewing national bank of Ethiopian annual reports of the year 2008-2018 and articles on development of financial sector in Ethiopia for open discussion.
\end{abstract}

Keywords:Financial Sector, Economic Development, National Bank of Ethiopian Annual Reports, Ethiopia DOI: $10.7176 /$ RJFA/10-5-01

Publication date:March $31^{\text {st }} 2019$

\subsection{INTRODUCTION}

This article provides an overview of the Financial Sector Development and Economic Growth of the country and begins with discussing the financial sector Developments in Ethiopia and the functions that a financial system provides in facilitating growth. The next section discusses an overview of the country's economic status and describes the major social and macroeconomic performance for the period 2008-2018; then GDP composition and its trends followed by the poverty profile of the country and its trends.. The third section focuses on relationship b/n financial sector development and economic growth. Finally, the last section concludes.

\subsection{GENERAL OVERVIEW OF FINANCIAL SECTOR STRUCTURE IN ETHIOPIA}

The financial sector currently operating in Ethiopia composed of formal, semiformal and informal institutions. The formal financial system is a regulated sector which comprises of financial institutions such as banks, insurance companies and microfinance institutions. The saving and credit cooperative are considered as semiformal financial institutions, which are not regulated and supervised by National Bank of Ethiopia (NBE). The informal financial sector in the country consists of unregistered traditional institutions such as Iqub (Rotating Savings and Credit Associations) Idir (Death Benefit Association) and money lenders. The formal financial sector components are discussed in detail in the following headings.

\subsubsection{FORMAL FINANCIAL SECTOR}

Banks, insurance companies and micro-finance institutions were the major financial institutions operating in Ethiopia

\subsubsection{BANKING SECTORS}

Banking in Ethiopia started in 1905, with the establishment of the Bank of Abyssinia that was owned by the Ethiopian government in partnership with the National Bank of Egypt then under British rule. But a well structured banking system started to evolve starting in the 1940s-after the Italian departure. A government owned bank-the State Bank of Ethiopia-was established in 1942, and a number of foreign bank branches and a private bank were operating in competition with the government owned commercial bank until they were nationalized and merged into one government owned mono-bank in 1976. The competitive banking situation that started to flourish during the 1960s and 1974s was nipped in the bud by the command system that reign over the 1974-1991 periods.

Following the change of government in 1991, and the subsequent measures taken to liberalize and reorient the economy towards a system of economy based on commercial considerations, the financial market was deregulated. A proclamation number 84/94 was issued out to effect the deregulation and liberalization of the financial sector, and a number of private banks and insurance companies were established following the proclamation. Directives issued in subsequent years further deepen the liberalization mainly including the gradual liberalizations of the interest rate, foreign exchange determination, and money market operation.

Currently, the number of banks still remained 18, of which 16 are private and 2 are state-owned.

In 2017/18, banks opened 500 new branches, raising the total number of branches to 4757 from 4257 in the 
previous year. The Total population is $96,503,000$ according to central stastical agency (CSA) estimation for 2018; As a result, bank branch to population ratio stood at 1:20,286.5 people in $2017 / 18$. About 35.3 percent of the total bank branches were located in Addis Ababa.

Although one can observe a strong growth and revival of the private sector since liberalization in the 1990s; yet, the state-owned banks seem to dominate the industry. As of the year 2017/18, the state owned banks account for $65 \%$ of total deposits and $55 \%$ of outstanding loans and advances and 60.1 percent of the capital.

More specifically, the state - owned Commercial Bank of Ethiopia (CBE) - the largest bank in Ethiopia alone controls about $28.8 \%$ of the branch networks, nearly $51.1 \%$ of the capital , about $46 \%$ of the outstanding loans and advances, and about $58 \%$ of the deposits of the commercial banks.

Table 1 provides the share of capital and branch network of Ethiopian Banks as of the year 2017/18. Total capital of the banking industry increased by 10 percent and reached Birr 85.8 billion by the end of June 2018

Table 1: Capital and branch share of the formal Banks in Ethiopia as of 2017/18(Capital in million ETB1)

\begin{tabular}{|l|l|l|l|l|}
\hline \multicolumn{1}{|l|}{ Total Capital } & \multicolumn{1}{l}{ Branches } \\
\hline Banks & Amount & Share & Number & Share \\
\hline Public Bank & & & & \\
\hline Commercial Bank of Ethiopia & $\mathbf{4 3 , 8 5 1 . 8}$ & 51.1 & 1375 & 28.9 \\
\hline Development Bank of Ethiopia & $7,616.5$ & 9.0 & 107 & 2.2 \\
\hline Total Public Banks & $\mathbf{5 1 , 5 2 8 . 3}$ & $\mathbf{6 0 . 1}$ & $\mathbf{1 4 8 2}$ & $\mathbf{3 1 . 2}$ \\
\hline Private Banks & & & & \\
\hline Awash International Bank & $4,210.0$ & 4.9 & 382 & 8.0 \\
\hline Dashen Bank & $3,725.6$ & 4.3 & 381 & 8.0 \\
\hline Abyssinia Bank & $3,265.8$ & 3.8 & 284 & 6.0 \\
\hline Wegagen Bank & $3,195.7$ & 3.7 & 292 & 6.1 \\
\hline United Bank & $2,579.9$ & 3.0 & 233 & 4.9 \\
\hline Nib International Bank & $2,991.4$ & 3.5 & 228 & 4.8 \\
\hline Cooperative Bank of Oromiya & $1,924.6$ & 2.2 & 332 & 7.0 \\
\hline Lion International Bank & $1,479.7$ & 1.7 & 210 & 4.4 \\
\hline Oromia International Bank & $1,890.0$ & 2.2 & 260 & 5.5 \\
\hline Zemen Bank & $1,391.8$ & 1.6 & 25 & 0.5 \\
\hline Buna International Bank & $1,667.7$ & 1.9 & 176 & 3.7 \\
\hline Berhan International Bank & $1,936.5$ & 2.3 & 168 & 3.5 \\
\hline Abay Bank & 1514.7 & 1.8 & 162 & 3.4 \\
\hline Addis International Bank & 789.6 & 0.9 & 59 & -1.2 \\
\hline Debub global bank & 614.3 & 0.7 & 43 & 0.9 \\
\hline Enat bank & $1,045.4$ & 1.2 & 40 & 0.8 \\
\hline Total Private Banks & $\mathbf{3 4 , 2 2 2 . 8}$ & $\mathbf{3 9 . 9}$ & $\mathbf{3 2 7 5}$ & $\mathbf{6 8 . 8}$ \\
\hline All Banks & $\mathbf{8 5 , 7 5 1 . 2}$ & $\mathbf{1 0 0 . 0}$ & $\mathbf{4 7 5 7}$ & $\mathbf{1 0 0 , 0}$ \\
\hline Source; national bank of Ethiopan & & \\
\hline
\end{tabular}

Source; national bank of Ethiopia annual report 207/2018

\subsubsection{THE INSURANCE SECTOR}

Likewise to banking, Ethiopia's insurance industry is undeveloped. Its emergence is traced back to the establishment of the Bank of Abyssinia in 1905. The Bank had been acting as an agent for foreign insurance companies to underwrite fire and marine policies. Before liberalization the command economy including political instability had been the stumbling block for the growth of the financial sector in Ethiopia. The 1990's ushered in economic liberalization that led to the revival of private sector participation in the financial sector. This has led to the formation of a number of private insurance companies 
Table 2: Total Capital and branch in numbers insurance companies in Ethiopia as of 2017/18(Capital in million ETB1)

\begin{tabular}{|l|l|l|}
\hline & Total Capital & Branches \\
\hline Insurance companies & Amount in million & Number \\
\hline Ethiopian Ins. Cor. & $\mathbf{1 5 3 0}$ & $\mathbf{8 5}$ \\
\hline Awash Ins.Com.S.C. & 439 & 44 \\
\hline Africa Ins.Com S.C & 294 & 28 \\
\hline National Ins. Co. of Eth. & $\mathbf{1 6 6}$ & $\mathbf{3 4}$ \\
\hline United Ins.Com. S.C & $\mathbf{3 6 8}$ & $\mathbf{3 7}$ \\
\hline Global Ins. Com.S.C & 148 & 16 \\
\hline Nile Ins.Com.S.C & 436 & 40 \\
\hline Nyala Ins.Com.S.C & 516 & 31 \\
\hline Nib Ins. Com.S.C & 313 & 39 \\
\hline Lion Ins. Com.S.C & 131 & 31 \\
\hline Ethio-Life Ins.Com.S.c & & \\
\hline Oromia Ins.Com.S.c & 112 & 20 \\
\hline Abay Insurance & 295 & 38 \\
\hline Berhan insurance S.C & 260 & 25 \\
\hline Tsehay Insurance S.C & 112 & 13 \\
\hline Lucy & 119 & 19 \\
\hline Bunna Insurance S.C. & 129 & 15 \\
\hline Total & 108 & 17 \\
\hline Source; national bank of Ethiopia annal & $\mathbf{5 4 7 6}$ & $\mathbf{5 3 2}$ \\
\hline
\end{tabular}

Source; national bank of Ethiopia annual report 207/2018

According to the National Bank of Ethiopia (2018) the number of insurance companies remained at 17, their branches increased to 532 following the opening of 40 new branches in 2017/18 alone. About 53.6 percent of insurance branches were situated in Addis Ababa and 84 percent of the total branches were private owned. Insurance companies increased their total capital by 26.4 percent to Birr 5.5 billion of which the share of private insurance companies was 72.1 percent and that of public insurance company was 27.9 percent.

According to Gebreyes (2011) the insurance market is undeveloped, uncompetitive and there exist paucity of information on the kind of life insurance that is currently present.

The current practice of bulk of insurance coverage and business in Ethiopia is targeting the corporate market and focuses mainly on general insurance with a very limited coverage in life insurance. The insurance sector is dependent on the banking sector for much of its new business. Most Ethiopian insurance companies have sister banks and its common for these banks to refer their clients to their sister insurance companies, but this is largely restricted to credit life insurance products. Moreover, insurance companies tend to derive a large portion of their total income from investments in banks (Smith and Chamberlain, 2009).

\subsubsection{MICROFINANCE INSTITUTIONS}

The emergence of Microfinance institution is a recent phenomenon in Ethiopia compared to other developing countries. The first microfinance service in Ethiopia was introduced as an experiment in 1994, when the Relief Society of Tigray (REST) attempted to rehabilitate drought and war affected people through the rural credit scheme. It was inspired by other countries' experiences and adapted to the conditions of the Tigray region (northern part of Ethiopia). In the second half of the 1990s, as a result of its success, the microfinance service was gradually replicated in other regions (Berhanu and Thomas, 2000).

Similar to microfinance approaches in many other parts of the world, MFIs in Ethiopia focus on groupbased lending and promote compulsory and voluntary savings. They use joint liability, social pressure, and compulsory savings as alternatives to conventional forms of collateral (SIDA, 2003). These institutions provide financial service, mainly credit and saving and, in some cases, loan insurance. The objectives of MFIs are quite similar across organizations. Almost all MFIs in the country have poverty alleviation as an objective. They focus on reducing poverty and vulnerability of poor households by increasing agricultural productivity and incomes, diversifying off farm sources of income, and building household assets. They seek to achieve these objectives by expanding access to financial services through large and sustainable microfinance institutions.

According to national bank of Ethiopia currently, there were 38 micro-finance institutions

(MFIs) operating in the country. These MFIs mobilized Birr 32,4 billion in saving deposit which was 20.8 percent higher than last year same period. Total outstanding credit of the MFIs increased 34.3 percent to Birr 46.8 billion signifying the growing role of the institutions in poverty reduction and wealth creation among low income groups both in rural and urban areas. Their total asset also grew by 24.7 percent to reach Birr 67 billion at the end of 
September, 2018.

\subsubsection{SEMIFORMAL - SAVING AND CREDIT COOPERATIVES}

In Ethiopia there are three types of saving and credit cooperatives, namely Institution based SACCOs; Community based SACCOS; and SACCOs sponsored by NGOs. Savings and credit cooperatives are type of organizations providing financial services to the poor in rural areas of Ethiopia. These include multi-purpose and credit and saving cooperatives. Unlike other formal financial institutions (banks and micro finance institutions), saving and credit cooperatives are owned, controlled and capitalized by their members. This implies that the savings and credit cooperatives are not subjected to supervision and regulation of the National Bank of Ethiopia. The ministry of cooperatives is responsible for the coordination of their activities. One of the principles of SACCOs is that lending is limited to only members of the cooperatives and the amount of loan depends on the level of individual saving deposits. One of the weaknesses reflected in the co-operative sector is poor administrative and financial management. On the other hand the government through the relevant ministry is not adequately equipped to monitor and control the cooperative movement. Savings and credit cooperatives in Ethiopia are not permitted to take deposits from non- members. Many rural saving and credit cooperatives provide loan services foragricultural inputs, animal fattening and in some cases for off farm activities. Loan disbursement policies are prudent, only those with sufficient savings and collateral can lend. The majority of loans are provided for a period of one year or less. Usually interest on loans is higher than charged by commercial banks but often lower than that of MFI's and definitely lower than the money lenders rate. At the end of 2006, almost 5500 SACCOs served more than 380000 members with savings and credit services. According to the Cooperative Agency (CA), SACCOs mobilized 994 million Birr (US\$111 million) from member contributions. The average deposit size of a single SACCO member is 2626 Birr (US\$293).

\subsubsection{INFORMAL FINANCE SECTOR}

In both rural and urban areas in Ethiopia, it is common that neighboring family households organize themselves and develop their own institutions, popularly known as Community-Based Organizations (CBOs). The nature of the CBOs highly varies from social, religious and financial concerns, but are all aimed to address the needs of the people. In most communities, membership in traditional community associations such as iddirs, iqqubs and mehabers are very common. More importantly, these traditional institutions also play a crucial role in savings and beneficiary mobilization in the informal financial sector.

According to Micro Ned (2007), the outreach of the informal financial sector is high; more than two thirds of the population have access to an informal finance provider, whether it is from money lenders, friends/relatives, or from one of the three popular systems (iddirs, iquips and mehabers) of informal finance. The price of informal credit fluctuates greatly from $10.5 \%$ per month on average from money lenders and traders to $0 \%$ from relatives and friends (ibid).

According to Micro Ned (2011), the informal finance has been popular due to three main reasons. First, it has more often than not been the only form of service delivery available. Second, loan processing is quick and not too many questions are being asked about the application of the borrowed sum. Third, in the case of Iddir and Iqqub, loans are provided in the context of social intermediation and self-organization. The capacity of these traditional systems, however, is limited (Ibid). The three most common informal finance or traditional institutions are discussed in detail in the following subheadings.

\subsubsection{IDDIRS}

An Iddir is the most common informal institution in Ethiopia, common in both rural and urban areas. It is an association made up by a group of persons united by ties of family and friendship, by living in the same district, by jobs, or by belonging to the same ethnic group and as an object of providing mutual aid and financial assistance in certain circumstances. It is primarily a burial society whereby savings are made to cover the cost of funerals, but also weddings. Whenever a death occurs among its members, the organization raises an amount of money to handle the burial and other related ceremonies. It further aims to address different community concerns and provides various services to its members. Membership is regularly by residence, whereby members pay a small monthly fee (Pankhurst and Mariam, 2000).

In practice Iddir is a sort of insurance programme run by a community or a group to meet emergencies. Iddir, unlike the insurance system is very popular among people because it is culturally appropriate, flexible, easily accessible and cost-effective. It is basically a non-profit making institution based upon solidarity, friendship, and mutual assistance among members.

In general, individuals tend to join iddirs when starting to have a family. Membership of iddirs is also increasingly widespread particularly among the poorest members of society, who are in most need of their support. Only new migrants without a fixed address and those who cannot afford the fees (the most impoverished of society) lack membership, and are consequently without the only form of social insurance that currently exists in Ethiopia (Ibid). Most of the associations are however not officially registered due to the high cost of registration. As a consequence, most iddirs remain unable to open bank accounts, obtain credit, or become partners with the government or NGOs in development activities (ibid). 
Concerning its organizational structure, nearly all iddirs have a secretary and a treasurer as well as a chairman and judge. Due to its impartial membership structure, it is often said to be Ethiopia's most democratic and egalitarian social organization where membership is open to anyone regardless of religion, socioeconomic status, gender and ethnic affiliation (Johansson, 2010)

During the current rule of the Ethiopia Peoples Revolutionary Democratic Front (EPRDF), the potential of iddirs as a vehicle for development has been further acknowledged by both the government as well as by nongovernmental institutions (NGOs). From the government's point of view, the general recognition of civil society's role in development has led to that iddirs have been accepted as possible partners for successful and sustainable development (Pankhurst et al., 2009).

\subsubsection{IQQUBS}

Iqqubs have played a significant role especially for the informal sector in Ethiopia. An iqqub is a traditional saving and credit association (Rotating Saving and Credit Association), of which its purpose is basically to pool the savings of their members in accordance with the rules established by the group. Members usually deposit contributions on a weekly or monthly basis, and lots are drawn by turns so that the one who wins the chance gets the total sum. This process continues on a regular basis until the last member receives his/her share or what she/he has been saving through the months and the whole process starts again

\subsubsection{MEHABERS}

Another common $\mathrm{CBO}$ is the Mehaber, which is a religious, informal institution that aims to raise funds for medical and burial expenses. It is widespread among the Orthodox Christians of Ethiopia, as it typically draws its members from the church. Members usually meet on a monthly basis for food and drink, and commonly support each other in times of difficulty (Pitamber, 2003).

\subsection{OVERALL FINANCIAL SECTOR DEVELOPMENTS IN ETHIOPIA}

The Ethiopian financial sector has remained safe, sound, well capitalized and profitable.

The banks also increased their deposit mobilization by 23.6 percent, loan collection by 14.9 percent and loan disbursement by $5.9 \%$. Similarly, insurance companies and microfinance institutions have scaled up their services by expanding their network and product diversification.

Notwithstanding the general positive outlook alluded above, the financial sector in the country is still shallow and reserved for local investors who are thus protected from global competition and best practice in the industry

Right now, the financial sector of Ethiopia is not serving the needs of the economy you expect from a country that is the second most populous in Africa due to the following argument:

* Total banking sector assets per capita in 2016 stood at about \$225 less than neighborhood Kenya \$782

* The bank per capita in Ethiopia, which is about 5.7 million populations for one bank, is one of the lowest in Africa

$\$$ Real rate of return are negative for savers using bank. The average saving interest rate is $7 \%$ but the country regularly records double digit inflation

4 The market dominance of CBE has proved to be a contentious issue the controversial issue of opening the financial system to foreign banks remains on the table

\subsubsection{Financial Sector Development and Economic Growth}

The connection between the operation of the financial system and economic growth has been one of the most heavily researched topics in development economics. Hundreds of scholarly papers have been written to conceptualize how the development and structure of an economy's financial sector affect domestic savings, capital accumulation, technological innovation, and income growth, or vice versa; and to empirically test these linkages including identifying directions of the causality and their relative importance using cross-country; country-specific; and industry-, firm-, and project-level data.

Economists believe that the most important role of the financial sector in facilitating growth is to reduce information, enforcement, and transaction costs. This is achieved through a number of specific functions that the financial sector performs. On the basis of an extensive survey of the literature, Levine (2004) identified and summarized five key functions that a financial system provides in facilitating growth:

\section{i Mobilizing and pooling savings}

Savings mobilization as a process of agglomerating capital from diverse savers for investment is very costly. Mobilizing savings involves overcoming transaction costs and informational asymmetry problems. Financial systems that are more effective at pooling the savings of individuals promote economic development by increasing savings, exploiting economies of scale, and overcoming investment indivisibilities. With large, indivisible projects, financial arrangements that mobilize savings from many diverse individuals and invest in a diversified portfolio of risky projects facilitate a reallocation of investment toward higher return activities with positive implications for economic growth. Better savings mobilization also boosts technological innovation and improves resource allocation. 


\section{* Producing information ex ante about possible investments and allocating capital}

Individual savers face high costs of acquiring and processing information on firms, managers, and market conditions, which could prevent capital from flowing to its best uses. Financial intermediaries reduce information costs through specialization and economies of scale and thereby improve resource allocation and accelerate growth. Improved information also helps identify the best production technologies and those entrepreneurs with the best chances of successfully initiating new goods and production processes. Stock markets may also stimulate the generation of information about firms. As markets become larger and more liquid, agents may have greater incentives to expend resources in researching firms because it is easier to profit from this information by trading in big and liquid markets.

\# Monitoring investments and exerting corporate governance.

The degree to which the providers of capital (shareholders and creditors) can effectively monitor and influence how firms use their capital and induce managers to maximize firm value - that is, to resolve the "agency problem" arising from the separation of ownership from control through effective corporate governance mechanisms - has important implications for savings, decisions for allocating the savings, and their utilization. Good corporate governance helps improve the efficiency with which firms allocate and utilize resources and makes savers more willing to finance production and innovation. Although there are countervailing arguments, many believe that monitoring and disciplining by creditors (banks or bondholders), shareholder activism exercised by institutional investors (such as banks, pension funds, etc), threat of takeovers and market for corporate control, threat of insolvency, and capital market competition, among others, are effective mechanisms for strengthening corporate governance.

\section{+ Facilitating trading, diversification, and management of risks}

Financial systems help mitigate the risks associated with individual projects, firms, industries, regions, and countries, etc. A financial system's ability to provide risk diversification services affects long-run economic growth by improving resource allocation and encouraging savings. Cross-sectional risk diversification stimulates technological innovation since engaging in innovation is risky, and the ability to hold a diversified portfolio of innovative projects reduces risk and promotes investment in growth-enhancing innovative activities. Besides cross-sectional risk diversification, financial systems also improve inter-temporal risk sharing and smoothing across generations. Further, financial systems enhance liquidity, reduce liquidity risks, increase investment in longer-term, higher-return, but illiquid assets, and promote economic growth.

\section{* Facilitating the exchange of goods and services.}

A financial system facilitates transactions in the economy, both by physically providing the mechanisms to make and receive payments and by reducing transaction and information costs as described earlier. Therefore, the financial sector facilitates trading of goods and services, and promotes specialization, technological innovation, and growth. Transaction and information costs may continue to fall through financial innovation. More specialization requires more transactions, and more transactions lead to greater specialization. In this way, markets that promote exchange encourage productivity gains. There may also be feedback from these productivity gains to financial market development, and thus economic development can spur the development of the financial sector.

Through these functions, financial sector development facilitates economic growth-not only by promoting private sector development, but also by supporting the public sector to invest in infrastructure and by enabling households to invest in human capital and benefit from consumption smoothing.

\section{\# Public sector}

Large and liquid bond markets are an integral component of a developed financial sector that enable the government to raise relatively cheap capital to invest in key infrastructure such as roads, power plants, harbors, airports, water supply and sanitation, and telecommunications. These key infrastructure facilities form part of the enabling environment for the private sector to grow. Moreover, active bond markets can discipline the government, thereby reducing the risks of financial crises - and prevent crowding out of private investments.

\section{\& Households}

Households are important players in the financial sector, both as savers and borrowers. Financial sector development brings benefits to households by increasing returns on and reducing risks of their invested savings. Savings enable households to smoothen their consumption. Households also borrow for a variety of reasons. By increasing consumption, the demand for goods and services increases thus stimulating more agricultural and industrial production, leading to more jobs and higher economic growth

The financial sector and its role in the process of economic development have attracted notable attention since the early 1990s. Long-term sustainable economic growth depends on the ability to raise the rates of accumulation of physical and human capital, to use the resulting productive assets more efficiently, and to ensure the access of the whole population to these assets. Financial intermediation supports this investment process by mobilizing household and foreign savings for investment by firms; ensuring that these funds are allocated to the most productive use; and spreading risk and providing liquidity so that firms can operate the new capacity 
efficiently.

Financial development thus involves the establishment and expansion of institutions, instruments and markets that support this investment and growth process. Historically the role of banks and non-bank financial intermediaries ranging from pension funds to stock markets, has been to translate household savings into enterprise investment, monitor investments and allocate funds, and to price and spread risk.

Liberalization of financial markets allows financial deepening which reflects an increasing use of financial intermediation by savers and investors and the monetization of the economy, and allows efficient flow of resources among people and institutions over time. This encourages savings and reduces constraint on capital accumulation and improves allocate efficiency of investment by transferring capital from less productive to more productive sectors.

The efficiency as well as the level of investment is thus expected to rise with the financial development that liberalization promotes. These benefits include a decrease in firms' in self-investment at low and even negative rates of return, allocation of credit by capital markets rather than by public authorities and commercial banks, a shift away from capital-intensive investments due to the higher cost of capital reflecting its scarcity, the lengthening of financial maturities, and the elimination of fragmented and inefficient curb markets. Development of the financial system facilitates portfolio diversification for savers reducing risk, and offers more choices to investors increasing returns. Another important function of financial system is to collect and process information on (productivity-enhancing) investment projects in a cost effective manner, which reduces cost of investment for individual investors.

In fact, financial systems serve five broad functions. First, they produce information ex ante about possible investments. Second, they mobilize and pool savings and allocate capital. Third, they monitor investments and exert corporate governance after providing finance. Fourth, they facilitate the trading, diversification and management of risk. Fifth, they ease the exchange of goods and services. While all financial systems provide these financial functions, and each of these functions can be expected to have an impact on economic growth, there are large differences in how well they are provided.

\subsection{RELATION SHIP B/N FINANCIAL SECTOR DEVELOPMENT AND ECONOMIC GROWTH}

In practice, there are two views on the importance of the financial system during development. The first view is that the financial sector does not matter very much, and that any correlation between financial development and growth is a result of growth leading development. The second view is that an efficient financial system is key to development. The later view with which am in favor, contended that financial development causes economic development - that financial markets promote economic growth by funding entrepreneurs and in particular by channeling capital to the entrepreneurs with high return projects.

The role of the financial system is to intermediate between lenders and borrowers, providing a menu of saving vehicles with differing risk and return characteristics, and helping investors find the financing they need, taking into account the returns and risks on the projects they wish to undertake. In carrying out their functions, financial intermediaries reduce transactions costs for savers and investors and help reduce problems of asymmetric information that are inherent in the relationships between investors and entrepreneurs. And to an important and increasing extent, the development of sophisticated derivative instruments has helped improve the allocation of risk in the economy, and increase the efficiency of the saving-investment process. For a given level of saving, more efficient financial intermediation increases the productivity of investment. It thus seems obvious that the more efficient the financial system, the more rapid the growth rate.

Financial markets not only allow risk diversification on the part of savers, they also facilitate risk diversification that affects technological change. By making it possible to hold a diversified portfolio of investments in risky technology projects, the markets enhance investment in growth-enhancing R\&D. Further, financial institutions play a role in evaluating entrepreneurs and projects. Better financial systems improve the probability of successful innovation and thereby accelerate economic growth. Financial institutions play an active role in evaluating, managing, and funding the entrepreneurial activity that leads to productivity growth.

Sound and sophisticated financial system promotes the efficiency of investment and economic growth in a market economy. It is also obvious that a poorly functioning financial system can hamper economic growth and development. The development of this sophisticated technical capacity has been essential to the growth of national financial systems and indeed the global financial system. It is also essential to the capacity of the financial system to allocate risk efficiently, an area of rapid technical progress. As is well known, the derivatives markets have grown at an explosive rate. By now the notional value of outstanding OTC derivative contracts is around \$150 trillion, with the nominal amount of exchange traded contracts adding about another $\$ 25$ trillion for a total about four times the volume of annual global GDP. However it is also well known that these spectacular numbers are highly misleading, for the market value of these contracts is probably only about 5 percent of their nominal value, and - taking into account legal netting - their net value is smaller yet. Still, the existence of these instruments does make a major contribution to reallocating risk in the economy towards those 
most prepared to bear it, for a price. And that does increase market stability.

Derivatives have a great potential for abuse in markets of such speed, volume and complexity. They place exacting demands on both internal risk control mechanisms and on the official regulatory systems. We should worry about transactions that can be kept off balance sheet, and applaud the progress that is being made in doing the right accounting for these instruments, difficult as the distinction between net and gross positions makes that. We should also worry about where the risks that are being hedged are ultimately held - for generally these risks are reallocated, not eliminated from the system.

As the economy develops, the financial system can become more sophisticated with it. At what rate? One answer - the financial repression argument - is that the development of the financial system should be held back by regulation. Another, the answer I prefer, is that the financial system should be allowed to develop more rapidly relative to per capita GDP than has been the historical norm - that a modern financial system can increase the efficiency of investment and contribute to growth both by reducing the costs of intermediation and by improving the allocation of risk. In any country, but especially in a developing country, economic policy has a special obligation to help the poorest.

There is some evidence that financial development directly benefits the poorer segments of society does low inflation. The development of microfinance, which makes small loans to poor people, also holds out promise of making a difference to the lives of the poor. By some estimates, microfinance now reaches over 50 million people worldwide, and in some countries microfinance is beginning to move into the more formal financial sector. The future of microfinance will be assured if it can become a viable commercial proposition - and this is well recognized by some of the leaders of the microfinance movement.

\subsection{FINANCIAL SECTOR REGULATION AND POLICY DIRECTIONS}

Innovation is clearly an important phenomenon in any sector of a modern economy. Although standard microeconomic theory (rightly) focuses much of its attention on the issues of static resource allocation and economic efficiency, there is nevertheless general appreciation that performance over time is driven by a variety of dynamic factors, including innovation

Ethiopia has embarked on automation of supervision functions and submission of regulatory returns/information from banks and microfinance institutions. With the objective of modernizing its bank and microfinance institutions supervisory functions and enhance the effectiveness and efficiency of its supervisory system, the National Bank of Ethiopia (NBE) implemented a system called Bank Supervision Application (BSA).

BSA is a system designed to automate banking supervision functions, in line with Basel Principles. It is a web based solution responsible for securing submission of financial information, validation and analysis and report generation. Ato Wubshet Fola, Principal Bank Examiner at NBE told Birritu that the system integrates three main supervision functions, in line with Basel Principles. It is a web based solution responsible for securing submission of financial information, validation and analysis and report generation

\section{$\checkmark \quad$ NATIONAL FINANCIAL INCLUSION STRATEGY (NFIS)}

Conceptually, financial inclusion is destined to promoting access and usage of suitable (quality and affordable) financial products and services through addressing barriers and challenges to financial inclusion, particularly pertaining to marginalized (unbanked, underserved, poor people and low income) people and enterprises. As global practice indicates, financial inclusion is achieved through formulating and implementing a national financial inclusion strategy. In this process, engagement of key stakeholders and coordination of their efforts are critical to deal with a number of cross cutting issues that have been causing and contributing to financial exclusion.

Financial inclusion in general terms is hoped to unlock the social and economic potentials and also expected to bring relative economic power, primarily to the low income and poor people through promoting investment in micro, small and medium enterprises (MSMEs) and agriculture sector that consequently promotes employment opportunities, rise in income and lead to healthy and responsible financial life. These eventually would help to alleviate poverty, improve living standard and welfare of the society. Moreover, financial inclusion supports and contributes its part towards achieving sustainable development goals (SDGs). In the case of Ethiopia, 11 out of 17 SDG would be directly supported if financial inclusion strategy is implemented as planned.

Digital Financial Services (DFSs) brings efficiency, easy access, affordable products and services, facilitate traceability of transactions (to ensure healthy financial transactions of consumers) and hence attracts demand for it from both supply and demand side.

Innovation is not only about technology. Products and services should also be innovative to fit into the technology ecosystem. There should also be innovative ways of disseminating knowledge and skill of the financial products and services to the actual and potential customers. At present, digital financial services (DFSs) are proved to be the most efficient and effective way of promoting financial inclusion. This is due to the fact that products and services are becoming easily accessible, usable and affordable. As DFSs avoids or minimizes the human intervention, consumers, particularly low income and poor people feel comfortable to transact through 
digital means and also avoids long distance travel to get the service as it can be supported by mobile phones. DFS is just emerging in Ethiopia. Banks, MFIs and Insurers have started offering products and services through digital means. Given the scale and potential the country endowed with, particularly in mobile money, DFSs is expected to boom in the near future. Mobile phones, beyond information exchange, can be used for financial transaction purposes. In this respect, the current and future potential for the development of ICT is expected to bring considerable growth and expansion in financial transactions. Banks, MFIs and Insurers, therefore, need to closely work with MCIT/Ethiotelcome to enhance, shift and transform their products and services to DFSs in line with best international practices and trends.

\section{$\checkmark$ INTERNATIONAL MONETARY FUND (IMF AND ETHIOPIAN FINANCIAL SECTOR}

The International Monetary Fund (IMF has praised Ethiopia's remarkable progress over more than a decade. The new legal framework for public-private partnerships can play an important role in strengthening growth by promoting private sector development and the provision of public services, while reducing government costs, says the report. It also calls for privatization and removal of barriers to private investment in key sectors, which supports policy announcements by the government.

The government also wants to develop the domestic financial system. An important first step will be to introduce a market for government securities with market-determined interest rates. This will allow the central bank to reduce direct financing of the government and increase the effectiveness of monetary policy in maintaining low and stable inflation. In their report, IMF staff encourages the authorities to review the strategy and financial model of the government's development lending agency - the Development Bank of Ethiopiawhich has seen lower-than-expected returns to its investments in recent years. A more flexible system for the exchange rate is also needed to increase foreign exchange reserves, improve external competitiveness, and increase the availability of foreign exchange. This would support the country's continued development.

A sound legal and policy environment is generally taken as a key prerequisite for the smooth operation and development of a financial system. In Ethiopia, the bedrock for the development of the financial sector was laid down in 1994 during which banking business proclamation No.84/94 was issued out. This proclamation ended the mono-bank system that reined for a decade and half, and gave a new lease of life to the financial sector in the country. Proclamation No.84/94 stipulates, among others, that a company should be licensed to carry out banking activities, defines the conditions for bank licensing. It also defines that banks are to be established as Share Company, wholly owned by Ethiopian nationals, and the NBE should approve any share ownership transfers.

Proclamation 84/94 also defines the business activities that a banking company should carry out in the country, and stipulates the amount of capital, both paid up and subscribed, its adequacy in relation to assets, the computation of legal reserves, the minimum liquidity and reserves requirements banks are required to hold, etc.

This Proclamation and subsequently issued out directives of the National Bank of Ethiopia defines the main functions and responsibilities of the commercial banks and other financial institutions. There are various directives (www.nbe.gov.et) that govern the operation of the banking industry. However, proclamation No.97/1998 is also worth mentioning at this juncture as it empowered the banks to foreclose collaterals and retrieve their loans without resorting to the court system and further discipline borrowers to respect contracts.

A legal framework for the establishment and operation of Micro finance institutions has also been provided by proclamation No. 40/1996. The proclamation stipulates that MFIs are to be established as share companies wholly owned by Ethiopians and should be licensed by the NBE. Following this proclamation, about 38 MFIs have been established, and the fragmented provisions of micro credits by various NGOs and government departments have now been better streamlined.

$\checkmark \quad$ Ethiopian Financial Reporting Proclamation and Regulation

Currently, the Ethiopian IFRS adoption has already been officially mandated by financial reporting proclamation No.847/2014 and Regulation No.332/2014 for the establishment of the regulatory body (AABE), which has already established its offices and started its activities. While this regulatory landscape is an outcome of the IFRS adoption processes conducted so far, they serve as precursor to the IFRS implementation in the future by reporting entities. They are not ends by themselves but the means to an end that is IFRS implementation and its effects in the Ethiopian business environment. Role of the accounting profession in the country's macroeconomic management and IFRS implementation in particular would be very significant

\section{$\checkmark$ LAUNCHING CAPITAL MARKET IN ETHIOPIA}

The establishment of stock markets in Ethiopia is expected to boost domestic savings and increase the quantity and quality of investment. More generally, stock markets are seen as enhancing the operations of the domestic financial system in general and the capital market in particular (Kenny and Moss, 1998). Critics, however, argue that the stock market might not perform efficiently in developing countries and that it may not be feasible for all African markets to promote stock markets given the huge costs and the poor financial structures (Singh, 1999).

Currently, the financial sector regulatory body, the National Bank of Ethiopia (NBE), announced that a secondary market dedicated to government bonds and other debt instruments is set to be introduced within a year 
and a half to be followed by similar markets for corporate bonds in the future.

The vice governor also said that the introduction of secondary market requires a well-thought-out preparedness to regulate corporate bonds that might be incorporated into the capital market in the future. The reason behind the cautious approach taken to introduce capital markets in Ethiopia relates to risks emanating from such sophisticated financial markets to the country's financial sector. Monitoring the disclosure of policies and the accounting and financial statements of corporations are some of the laborious activities which regulators have to undertake to run secondary markets or exchanges,

Veterans of the financial sector such as Eyesuswork Zafu, board chairman of United Bank, and Zemedeneh Negatu, managing partner of Ernst and Young East Africa, have challenged the stance taken by the central bank regarding secondary markets. According to Eyesus work, the call for the introduction of a formal secondary capital market has been echoed since 1990s.

Among the challenging questions during a presentation he made on the country's financial institutions entitled: "Missing Financial Institutions" at the first East Africa Finance Summit. In his paper, Yoahnnes argued that a phase by phase approach is essential in introducing secondary and stock exchange markets in Ethiopia. He also said it is just a matter of time that these markets will be introduced in Ethiopia. So far, the financial institutions in Ethiopia have facilitated the advent of primary capital market in country.

These indicate NBE to have strong regulatory framework that protects the interests of the public. Without a well-functioning and well-managed secondary market, it is dubious to try to resolve the existing problems in the primary markets in Ethiopia.

\subsection{CONCLUSION AND POLICY RECOMMENDATIONS.}

The country background shows that the country has been experiencing strong economic growth during the study period. Since new Prime Minister Abiy election has created space for a more inclusive political dialogue and has taken steps to bring stability to the region. On the economic front, the new government has announced an ambitious reform program for the country aimed at opening the economy to private investment and competition to support sustainable growth. In sector wise, the service sector has driven recent growth and yet the economy remains heavily reliant on agriculture. Indeed, the rapid growth over the years has helped in reducing the incidence of poverty in the country. The country's financial sector also seems to be flourishing only recently. Despite the improvement in the last couples of years, Ethiopian banking remains in its low status. For banking, the state-owned banks seem to dominate the industry. Surprisingly, the Commercial Bank of Ethiopia (CBE) the largest bank in Ethiopia CBE) alone controls or nearly half of the branch networks, capital, outstanding loans and advances, and more than half of the deposit of the country's banks.

In general, the challenges of implementation of IFRS IN ETHIOPA, further deregulation of financial sector and building the NBE's capacity to regulate and supervise them is becoming more critical issues for policy debate. In this regard the suggested policy directions are;-

$\checkmark$ IFRS implementation activities need to have more enrollments of national actors involving all the concerned stakeholders of the accounting profession, academia, private sectors, government, public enterprises and organizations, etc.

$\checkmark$ Fully liberalization of financial sector is not the option enhance financial sector it better to create partial liberalizations by building strong regulatory framework

$\checkmark$ According to Alemayehu Geda;2017 the * set of policies relate to a cautiously opening up of the financial sector as it cannot be protected forever, create a level playing field for the public and private financial sectors and time-specific capacity building for supervision and regulation at NBE in a very short time. The latter is important as the NBE's current capacity is weak to handle further liberalization that are getting complex by the day.

$\checkmark$ Better savings mobilization in financial systems that are more effective at pooling the savings of individuals promote economic development by increasing savings, exploiting economies of scale, and overcoming investment indivisibilities

$\checkmark$ The literature suggests that sound macroeconomic environment, well developed banking sector, transparent and accountable institutions and shareholder protection are necessary preconditions for the efficient functioning of capital market in Ethiopia.

\subsection{REFERENCES}

Accountants and Auditors Board of Ethiopia (AABE) five years strategic plan 2015/16-2020/21. (n.d.)..

Ball, R. (2006). International Financial Reporting Standards (IFRS): Pros and Cons for Investors . Accounting and Business Research ,36: , Sup1,5-27.

Addison, T and Alemayehu Geda (2001). 'Ethiopian Financial Sector and Its Regulation' in Tony Addison (2001). From Conflict to Recovery in Africa. Oxford: Oxford University Press.

Alemayehu and Kibrom Tafere (2011). 'The Galloping Inflation in Ethiopia: A Cautionary Tell for African 
Developmental States' in Alemayehu Geda (2011). Reading in Ethiopian Economy.

Addis Ababa: Addis Ababa University Press.

Alemayehu Geda (2011). Readings on Ethiopian Economy. Addis Ababa: Addis Ababa University Press.

Alemayehu Geda (1999). 'A Consistent Macro Database for Ethiopia', Addis Ababa: Ethiopian Economic Association, Background Paper.

Belay Gedey (1990). Money, Banking and Insurance in Ethiopia, Addis Ababa: Berhanena Selam Printing Press (In Amharic).

Brownbridge, M. and C. Kirkpatrick (1999). 'Financial Regulation in Developing Countries: A Critical Survey', Manchester: Institute for Development Policy and Management, University of Manchester (May).

Caprio, G. Jr. (1996). 'Bank regulation: the case of the missing model', Policy Research Working Paper 1574, Washington DC: World Bank.

Demirguc-Kunt, A. and E. Detragiache (1999). 'Financial liberalization and financial fragility', in B. Pleskovic and J. Stiglitz (eds) Proceedings of the 1998 Annual Bank Conference on Development Economics, Washington DC: World Bank: 303-31.

Dejene Aredo (2003).The Informal and semi-informal financial sector in Ethiopia: A study of the Iqqub, Iddir and Saving and Credit Cooperatives. African Economic research consortium. Research paper-21.

Dessalegn, and Aklilu, K. (1999). CONSULTATIONS WITH THE POOR. World Development.

Desta, E. (1995). Agricultural Producer Cooperatives : Some Lessons of Experience from Ethiopia. GeoJournal, $353-360$

Levine, R (1997), Financial development andconom,ic Growth: Views and Agenda. Journal of Economic Perspective.

Mauri, A. 1987.The role of financial intermediation in the mobilization and allocation of household saving in developing countries: Interlinks between organized and informal circuits: the case of Ethiopia. International experts meeting on the domestic savings mobilization, east-west center,Honolulu.2 4,June 1987

MoFED. (2002). Ethiopia: Sustainable Development and Poverty Reduction Program. Addis Ababa, Ethiopia.

Moges, T. (2006). Shocks,Livestock Asset Dynamics and Social Capital in Ethiopia.

National Bank of Ethiopia (NBE), (2011). A study on the need for establishing rural and urban micro-financial institutions in Ethiopia, January, Addis Ababa.

GOE-IMF (Government of Ethiopia and the International Monetary Fund) (1998). 'Ethiopia:Enhanced Structural Adjustment Facility; Medium-Term Economic and Financial Policy Framework Paper, 1998/99-2000/01', Washington DC: IMF,(www.imf.org/external/np/pfp/eth/etp.htm).

NBE (National Bank of Ethiopia) (1996b). 'Manual for Bank Licensing and Supervision',Addis Ababa, Unpublished document (April).

NBE (National Bank of Ethiopia) (2015). Annual Report 2017/18. Addis Ababa: NBE.Polizatto, V. (1993). 'Prudential regulation and banking regulation: building an institutional framework for banks', in P. Callier (ed.) Financial Systems and Development in Africa,

Washington DC: Economic Development Institute, World Bank: 173-99. 